\title{
VARIATIONS AMONG MAIZE (Zea mays L.) HYBRIDS IN RESPONSE TO HEAT STRESS: HYBRIDS SELECTION CRITERIA
}

\author{
Muhammad Irfan YOUSAF ${ }^{*}$, Muhammad Husnain BHATTI ${ }^{1}$, Aamir GHANI ${ }^{1}$, Aamar SHEHZAD ${ }^{2}$, Aamir \\ HUSSAIN ${ }^{1}$, Rahil SHAHZAD ${ }^{3}$, Muhammad Asad HAFEEZ ${ }^{1}$, Mudassar ABBAS ${ }^{2}$, Muhammad Umer \\ KHALID ${ }^{4}$, Naeem AKHTER ${ }^{4}$
}

${ }^{1}$ Maize and Millets Research Institute (MMRI), Yusafwala, Sahiwal, PAKISTAN

${ }^{2}$ Maize Research Station (MRS), AARI, Faisalabad, PAKISTAN

${ }^{3}$ Agriculture Biotechnology Research Institute, AARI, Faisalabad. PAKISTAN

${ }^{4}$ University of Sargodha, Department of Plant Breeding and Genetics, PAKISTAN

*Corresponding author: irfanpbg.uaf@gmail.com

Received: 15.05 .2020

\begin{abstract}
High ambient temperature is one of the most alarming climatic factors in challenging the productivity and sustainability of crops worldwide. An effective way to cope this problem is the development of climate smart, heat resilient maize hybrids through evaluating the cultivated germplasm. The main objective of current study was to evaluate local and multinational maize hybrids for their performance under optimal and heat stress conditions and to devise a selection criterion for the identification of heat tolerant maize hybrids. Nine maize hybrids, including local and multinational, were evaluated under optimal and heat stress conditions across three consecutive spring seasons (2017-18, 2018-19 and 2019-20) at Maize and Millets Research Institute, Yusafwala, Sahiwal. Results revealed the presence of highly significant differences among maize hybrids under both conditions and for all three seasons. Kernel yield was found to be highly correlated with net photosynthetic rate $\left(0.735^{* *}\right)$, shelling percentage $\left(0.910^{* * *}\right)$ and relative cell injury percentage $\left(-0.775^{* * *}\right)$ under stress conditions. Cluster and biplot analysis unveiled that two local maize hybrids YH-5507 and YH-5427 were highly heat tolerant while multinational hybrids i.e. NK-8711, P-1543 and DK-6724 were highly productive under control/optimal conditions only. These hybrids can be invaluable sources of genes/alleles for the development of climate smart maize genotypes.
\end{abstract}

Keywords: Biplot analysis, Climate smart, Heat tolerance, Multivariate analysis, Photosynthesis

\section{INTRODUCTION}

Maize is one of the most important and widely grown cereal crop of the world. It is the most productive cereal crop in terms of kernel yield per hectare. In 2018-19, it was cultivated on an area of 191.72 million hectares in more than 125 countries of the world and 1123.65 million metric tons of production was obtained with an average of 5.86 metric tons per hectares (USDA, 2020). Maize is predominantly used in poultry feed, livestock industry and human consumption. However, its demand in dry- and wet milling industry is increasing day by day, where it is used to produce many industrial products like oil, starch, alcoholic beverages, food sweeteners, pharmaceuticals, cosmetics, confectionery and several industrial chemicals etc. (Serna-Saldivar, 2019). Millions of people from the poorest regions of Africa, Asia and Latin America directly depends upon maize for their food and livelihood.

In Pakistan, maize is the $3^{\text {rd }}$ most important cereal crop after wheat and rice but rank $1^{\text {st }}$ in overall productivity. In 2018-19, it was cultivated on an area of 1.229 million hectares and 5.702 million metric tons production was obtained with an average of 4.640 metric tons per hectares (GOP, 2018-19). It is sown under two different cropping seasons; Spring and Autumn. Spring crop is sown in the months of February-March and harvested in June-July while autumn crop is sown in July-August and harvested in November-December. Kernel yield of spring crop is much higher than autumn due to better heat use efficiency (Yousaf et al., 2020). However, temperature higher than optimum level $\left(28^{\circ} \mathrm{C}-34^{\circ} \mathrm{C}\right)$ could drastically effect crop growth and development especially at reproductive stage (Sánchez et al., 2014).

Temperature is one of the most critical environmental factors that control and regulate the rate of growth and development in most of the crops. Every crop specie responds differentially under changing climatic conditions depending upon their threshold levels for minimum and maximum temperature. In maize, all the plant growth and development stages are markedly influenced by the sudden variations in ambient temperature and cause 
significant reduction in kernel yield. Rahman et al. (2013) reported that temperature higher than $35^{\circ} \mathrm{C}$ could reduce maize kernel yield at the rate of $101 \mathrm{~kg} \mathrm{ha}^{-1}$ day $^{-1}$. A global study also revealed that for every $1^{\circ} \mathrm{C}$ increase in upper level of temperature $\left(>29^{\circ} \mathrm{C}\right)$, maize yield could be reduced up to $10 \%$ (Brown, 2009). Iqbal et al. (2011) predicted an $8.1 \%$ decrease in maize kernel yield by 2055 due to the increase in ambient temperature in Pakistan. This decrease in yield is associated with the increased susceptibility of different plant organs and functions to high temperature. Increase in anthesis-silking interval (ASI) due to desynchronization of male and female plant parts results into reduced pollination, poor fertilization and seed setting which leads to drastic reduction in kernel yield (Cicchino et al., 2010; Dass et al., 2010). Furthermore, reduction in kernel yield is also significantly associated with the reduction in photosynthetic ability, thousand kernel weight, plant biomass, cell membrane thermostability, number of kernels per cob and shelling percentage (COŞKUN et al., 2011; Yousaf et al., 2017; Yousaf et al., 2018 and Noor et al., 2019). These findings suggest that there is an utmost need for the development of heat resilient maize hybrids, having the ability to withstand harsh climatic conditions like heat stress. This could be possible by real time, field screening of available cultivated germplasm on the basis of heat associated primary and secondary plant traits for not less than three years. Therefore, current study was planned to evaluated local and multinational maize hybrids under optimal and heat stress conditions for the period of three years/seasons. Furthermore, impact of high temperature on different physiological functions of plants and kernel quality traits was also determined.

\section{MATERIALS AND METHODS}

\section{Experimental Material, Site, Layout and Design}

The current experimental study was conducted at the research area of Maize and Millets Research Institute (MMRI), Yusafwala-Sahiwal, Pakistan. Nine spring maize hybrids including six local (YH-5427, YH-5482, YH5507, YH-5213, YH-5532 and YH-1898) and three wellestablished commercial hybrids (P-1543, DK-6724 and NK-8711) were tested under two different heat regimes for three consecutive spring seasons (2017-18, 2018-19 and 2019-20) (Table 1). First set of maize hybrids was sown under optimal conditions in $2^{\text {nd }}$ week of February and the $2^{\text {nd }}$ set of same hybrids was planted under late sowing (heat stress) conditions on $3^{\text {rd }}$ week of March. Late sowing was used as proxy for heat stress condition because in late sowing conditions, reproductive stage of hybrids was expected to coincide with high ambient temperature $\left(>40{ }^{\circ} \mathrm{C}\right)$, which can prove deadly to growth and development of these hybrids. Treatments were laidout under split-plot arrangement in randomized complete block design (RCBD). Each entry was laid out under $12 \mathrm{~m}^{2}$ net plot size, having $15 \mathrm{~cm}$ plant-to-plant while $75 \mathrm{~cm}$ row-to-row distance, respectively. Maize hybrids, replications, net plot size and sowing dates were kept same for all the three sowing seasons. Sowing was done with the help of dibbler @ 2 seeds per hill. At seedling stage, crop was thinned to single seedling to ensure optimum plant population. All the standard agronomic practices i.e. application of fertilizer, pre-emergence herbicides, pesticides and irrigation was applied to both optimal and stress sown crop.

Table 1. Salient Features of Maize hybrids used in the study

\begin{tabular}{cclccc}
\hline Sr. No & Hybrid Names & \multicolumn{1}{c}{ Origin } & Hybrid Status & Seed Types & Cob Type \\
\hline $\mathbf{1}$ & YH-5427 & MMRI, Yusafwala, Pakistan & Local check & Dent & Cylindrical \\
$\mathbf{2}$ & YH-5482 & MMRI, Yusafwala, Pakistan & Local promising hybrid & Dent & Cylindrical \\
$\mathbf{3}$ & YH-5213 & MMRI, Yusafwala, Pakistan & Local promising hybrid & Semi-Dent & Conical \\
$\mathbf{4}$ & YH-5532 & MMRI, Yusafwala, Pakistan & Local promising hybrid & Dent & Conical \\
$\mathbf{5}$ & YH-5507 & MMRI, Yusafwala, Pakistan & Local promising hybrid & Dent & Cylindrical \\
$\mathbf{6}$ & P-1543 & Corteva (Pioneer), Pakistan. & Multinational check & Semi Dent & Cylindrical \\
$\mathbf{7}$ & YH-1898 & MMRI, Yusafwala, Pakistan & Local check & Semi Dent & Conical \\
$\mathbf{8}$ & DK-6724 & Monsanto Seeds, Pakistan & Multinational check & Semi Dent & Cylindrical \\
$\mathbf{9}$ & NK-8711 & Syngenta, Pakistan & Multinational check & Dent & Cylindrical \\
\hline
\end{tabular}

MMRI, Yusafwala = Maize and Millets Research Institute, Yusafwala, Sahiwal, Pakistan

\section{Data Recording}

Data was recorded for yield and yield-associated traits including relative cell injury percentage (RCI\%), number of grains per cob (NGC), net photosynthetic rate (Pn; $\mu$ mole $\left.\mathrm{m}^{-2} \mathrm{~s}^{-1}\right)$, stomatal conductance $\left(\mathrm{C}\right.$; mmole $\left.\mathrm{m}^{-2} \mathrm{~s}^{-1}\right)$, grain protein content percentage (Prot.), grain oil content percentage (Oil), grain starch content percentage (Starch.), shelling percentage $(\mathrm{S} \%)$ and kernel yield per hectare (KY). Relative cell injury percentage (RCI\%) was measured by comparing the electrical conductivity (EC) of stressed and non-stress leaf discs as described by Naveed et al. (2016) by the following formula;

$$
\mathrm{RCI} \%=[1-\{1-(\mathrm{T} 1 / \mathrm{T} 2)\} /\{1-(\mathrm{C} 1 / \mathrm{C} 2)\}] \times 100
$$

Where,

$C 1$ and $C 2=1^{\text {st }}$ and $2^{\text {nd }}$ reading of electrical conductivity (EC) of non-stressed set of test tube

$T 1$ and $T 2=1^{\text {st }}$ and $2^{\text {nd }}$ reading of electrical conductivity (EC) of heat-stressed set of test tube

Net photosynthetic rate and stomatal conductance was measured between 10 am to 12 Noon through Infrared Gas Analyzer (IRGA), using a handled photosynthetic system (CI-340 by CID Bio-Science, USA). Grain quality analysis was carried out by using near infrared 
spectroscopy (NIR by Inframatic 9200, Parten Instruments, Sweden) to estimate grain protein (Prot.), oil (Oil) and starch (Starch) content percentage, respectively.
Kernel yield ( $\mathrm{Kg} / \mathrm{ha}$ ) was calculated through the following formula as described by Tandzi, and Mutengwa (2019);

$$
\text { Kernel Yield }(\text { Kg ha }-1)=\frac{\text { Fresh cob weight }(\mathrm{Kg} / \text { plot }) \times(100-\mathrm{MC}) \times 0.8}{(100-15) \times \text { Area Harvested } / \text { plot }} \times 10000
$$

\section{Statistical Data Analysis}

The recorded data was subjected for combined analysis of variance (ANOVA) according to Steel et al. (1973) to see statistical differences among maize hybrids under both optimal and heat stress conditions. Correlation coefficient analysis was carried out to compute degree and direction of correlation between different plant traits under both conditions. Furthermore, principal component (PCA) and agglomerative hierarchical cluster analysis (AHC) were used to characterize maize hybrids for their heat tolerance as introduce by Sneath and Sokal (1973) and used by Yousaf et al. (2018). Two statistical packages i.e. Statistix 8.1 and XLSTAT were used to compute data for different analysis. Microsoft Excel (Version 2019) was also utilized for the presentation of data in graphical form.

\section{Metrological conditions during the trial seasons}

Research trails were conducted in three consecutive spring seasons (2017-18, 2018-19 and 2019-20) (Figure $1)$. For all growing seasons, optimal set of maize hybrids was sown in the month of February and harvested in the month of June. Whereas, late sown (heat stress) set was planted in the $3^{\text {rd }}$ week of March while harvested during the month of July. Daily air temperature was recorded for both sets, consecutively for three growing seasons. Three season's average minimum and maximum temperatures were measured as $18.9{ }^{\circ} \mathrm{C}$ and $35.7{ }^{\circ} \mathrm{C}$ for optimal set while $22.5^{\circ} \mathrm{C}$ and $39.1^{\circ} \mathrm{C}$ for late sown (heat stress) set, respectively. The average maximum temperature during flowering and grain development stages in maize under heat stress conditions was recorded $41.7{ }^{\circ} \mathrm{C}$ which was detrimental to pollen viability, fertilization, seed setting and ultimately kernel yield in maize.

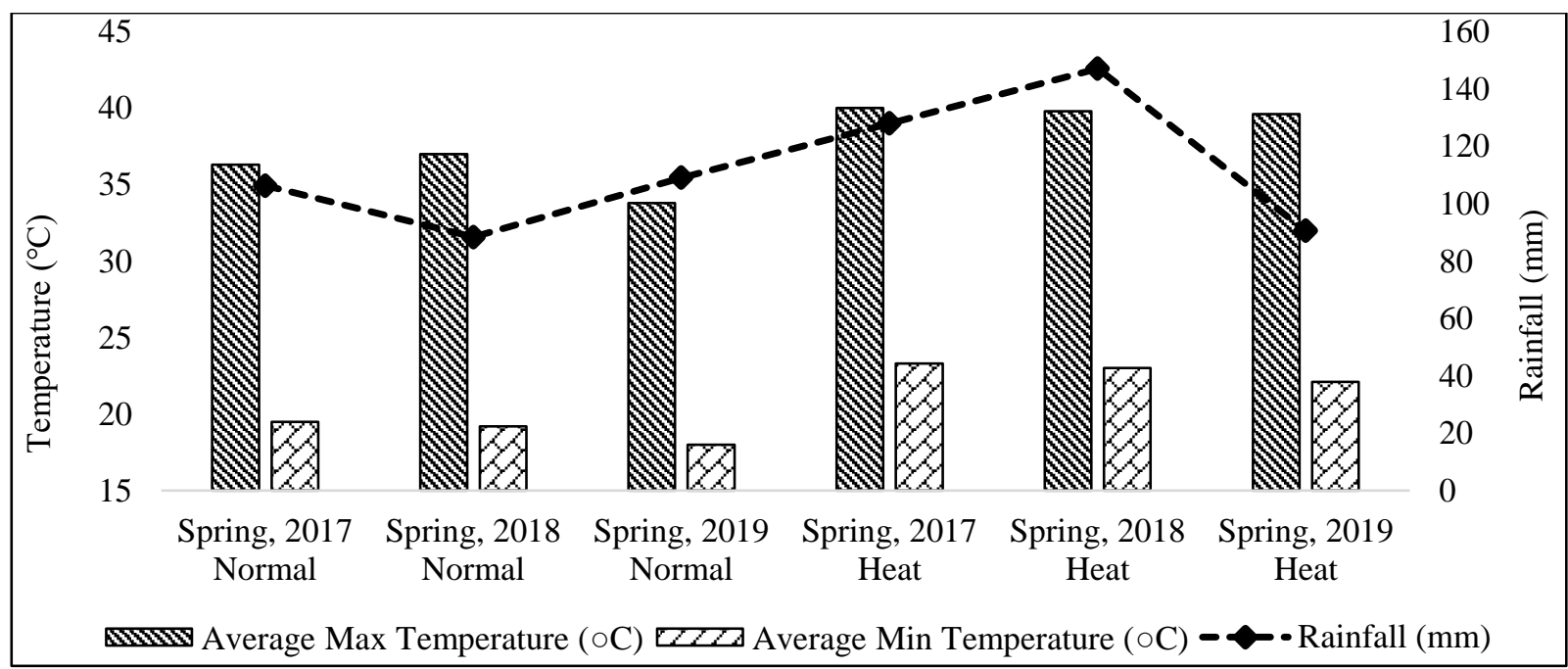

Figure 1. Meteorological data of optimal and heat growing seasons for three consecutive spring seasons (Spring 2017-18, 2018-19 and 2019-20)

\section{RESULTS AND DISCUSSION}

Analysis of Variance

Combined analysis of variance (ANOVA) showed significant differences $(p<0.01)$ among maize hybrids, sowing years/seasons, treatments (optimal and heat stress conditions) and interactions between these parameters except few, respectively (Table 2). However, interactions for kernel quality traits i.e. kernel protein and oil content percentage and shelling percentage were found nonsignificant. Similar results were reported by Saeed et al. (2018), Shehzad et al. (2019) and Cheema et al. (2020) who revealed the presence of significant differences among maize hybrids/germplasm for kernel yield and its associated traits under heat stress conditions.

\section{Correlation Coefficient Analysis}

Correlation coefficients were computed for different morpho-physiological and kernel quality traits under optimal and heat stress conditions. For this three year's average data of these traits were polled to get an overall average data for both sowing conditions (Table 3). The results revealed that kernel yield had a strong positive correlation with net photosynthetic rate $\left(r=0.958^{* *}\right)$ and 
shelling percentage $\left(\mathrm{r}=0.871^{* *}\right)$ under optimal sowing conditions while strong negative correlation with relative cell injury percentage $\left(-0.735^{* *}\right)$. Similarly, kernel yield had a positive and significant correlation with $P n$ (r = $\left.0.910^{* *}\right)$ and $\mathrm{S} \%\left(0.910^{* *}\right)$ while significantly negative association was found with RCI\% $\left(-0.775^{* * *}\right)$ under stress conditions (Table 3). The Correlation between kernel yield and thousand kernel weight was, however negative $(-0.251)$ under optimal conditions but under heat stress conditions, the correlation was positive $(0.585)$. This might be due to the fact that under stress conditions number of grains per cob get reduced due to sparse filling of cobs, which increase the dependence of kernel yield on thousand kernel weight. Similar observations were reported by Khodarahmpour, 2012, Yousaf et al. (2017) and Kandel et al. (2017) who found a positive correlation of kernel yield with photosynthesis, shelling percentage, number of kernels per cob and thousand kernel weight under heat stress conditions.

Table 2. Analysis of variance for kernel yield and related traits in maize hybrids for three spring seasons (2017-18, 2018-19 and 2019-20)

\begin{tabular}{|c|c|c|c|c|c|c|c|c|c|c|c|}
\hline SOV & DF & RCI\% & KC & TKW & Pn & $\mathbf{C}$ & Pro & Oil & Starch & S\% & KY \\
\hline Replications & 2 & 0.46 & 18.9 & 5.2 & 2.30 & 0.9 & 0.189 & 0.0029 & 0.036 & 0.907 & 29821.5 \\
\hline Hybrids & 8 & $34.6^{* *}$ & $57414.1^{* *}$ & $7552.6^{* *}$ & $153.8^{* *}$ & $16537.5^{* *}$ & $20.61^{* *}$ & $4.027^{* *}$ & $19.271^{* *}$ & $17.76^{* * *}$ & $10860000^{* *}$ \\
\hline Years & 2 & $742.1^{* *}$ & $3788.6^{* *}$ & $7214^{* *}$ & $241.4^{* *}$ & $1705.7^{* *}$ & $0.58^{* *}$ & $0.207^{* *}$ & $1.282^{* *}$ & $12.056^{*}$ & $25950000^{* *}$ \\
\hline Treatment & 1 & $272.2^{* * *}$ & $99062^{* *}$ & $11960.9^{\text {*** }}$ & $1009.5^{* *}$ & $6766.7^{* *}$ & $1.87^{* *}$ & $1.176^{* *}$ & $6.361^{* *}$ & $56.89^{* *}$ & $110400000^{* *}$ \\
\hline Hybrid*Year & 16 & $105.5^{* *}$ & $8544.8^{* *}$ & $476.7^{* *}$ & $22.83^{* *}$ & $1508.5^{* *}$ & $0.11^{\mathrm{NS}}$ & $0.059^{*}$ & $0.481^{* *}$ & $3.43^{\mathrm{NS}}$ & $2030920^{* *}$ \\
\hline Error $(\mathrm{H} \times \mathrm{Y})$ & 16 & 11.2 & 586.4 & 82.5 & 0.18 & 345.5 & 0.2 & 0.032 & 0.167 & 2.56 & 267043 \\
\hline Hybrid*Treatment & 8 & $9.7^{*}$ & $3724.7^{\text {** }}$ & $558.5^{* *}$ & $80.40^{* *}$ & $219.5^{* *}$ & $0.13^{\mathrm{NS}}$ & $0.018^{\mathrm{NS}}$ & $0.464^{* *}$ & $3.26^{\mathrm{NS}}$ & $2631676^{* *}$ \\
\hline Error $(\mathrm{H} \times \mathrm{T})$ & 8 & 3.4 & 402.4 & 94.5 & 3.27 & 90.4 & 0.21 & 0.014 & 0.127 & 2.51 & 286125 \\
\hline Year*Treatment & 2 & $25.7^{* *}$ & $12005.8^{* *}$ & $7472.9^{* *}$ & $274.6^{* *}$ & $492.7^{* *}$ & $0.777^{* *}$ & $0.016^{\mathrm{NS}}$ & $0.949^{* *}$ & $5.05^{\mathrm{NS}}$ & $6609754^{* *}$ \\
\hline Error $(\mathrm{Y} \times \mathrm{T})$ & 2 & 9.4 & 624.5 & 693.2 & 3.21 & 184.6 & 0.25 & 0.01 & 0.296 & 3.67 & 456723 \\
\hline Error $(\mathrm{H} \times \mathrm{T} \times \mathrm{Y})$ & 122 & 4.81 & 333.1 & 70.6 & 1.38 & 77.9 & 0.120 & 0.028 & 0.095 & 2.73 & 246043 \\
\hline
\end{tabular}

*Significant at $5 \%$ probability level, ** Significant at $1 \%$ probability level, NS= Non-significant

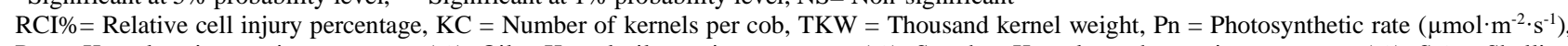
Pro $=$ Kernel grain protein percentage $(\%)$, Oil $=$ Kernel oil protein percentage $(\%)$, Starch $=$ Kernel starch protein percentage $(\%)$, S $\%=$ Shelling Percentage, GY = Kernel yield per hectare $\left(\mathrm{kg} \cdot \mathrm{ha}^{-1}\right)$

Table 3. Three years average data-based correlation coefficients between kernel yield and associated traits in maize hybrids for under optimal and heat stress conditions

\begin{tabular}{lcccccccccc}
\hline Variables & RCI\% & TKW & KC & Pn & C & Pro & Oil & Starch & S\% & KY \\
\hline RCI\% & 1 & -0.359 & 0.264 & $-0.711^{*}$ & 0.230 & -0.583 & -0.196 & 0.366 & $-0.682^{*}$ & $-0.775^{*}$ \\
TKW & 0.176 & 1 & -0.128 & 0.205 & 0.076 & -0.259 & -0.218 & 0.144 & 0.486 & 0.585 \\
KC & 0.591 & -0.246 & 1 & 0.074 & 0.568 & $-0.723^{*}$ & -0.433 & $0.773^{*}$ & -0.069 & 0.045 \\
Pn & -0.616 & -0.087 & -0.023 & 1 & 0.294 & 0.279 & -0.098 & -0.386 & 0.654 & $0.735^{*}$ \\
C & 0.012 & -0.267 & 0.414 & 0.642 & 1 & -0.655 & -0.171 & 0.148 & -0.044 & 0.037 \\
Pro & $-0.690^{*}$ & -0.020 & $-0.756^{*}$ & 0.012 & -0.494 & 1 & 0.482 & $-0.759^{*}$ & 0.256 & 0.174 \\
Oil & -0.318 & -0.366 & 0.023 & -0.089 & -0.070 & 0.521 & 1 & $-0.479 *$ & 0.107 & 0.037 \\
Starch & 0.515 & -0.089 & 0.420 & -0.094 & 0.019 & -0.627 & $-0.766^{*}$ & 1 & -0.143 & -0.061 \\
S\% & $-0.693^{*}$ & -0.051 & -0.078 & $0.929^{*}$ & 0.398 & 0.086 & -0.073 & -0.089 & 1 & $0.910^{*}$ \\
KY & $-0.674^{*}$ & -0.251 & 0.002 & $0.958^{*}$ & 0.633 & 0.075 & 0.041 & -0.127 & $0.871^{*}$ & 1 \\
\hline
\end{tabular}

** Significant at $1 \%$ probability level, Values in upper diagonal represent correlation coefficients under heat stress sowing while values in lower diagonal represent correlation coefficients under optimal sowing, RCI\%= Relative cell injury percentage, KC $=\mathrm{Number}$ of kernels per cob, TKW = Thousand kernel weight, $\mathrm{Pn}=$ Photosynthetic rate $\left(\mu \mathrm{mol} \cdot \mathrm{m}^{-2} \cdot \mathrm{s}^{-1}\right)$, Pro $=$ Kernel grain protein percentage $(\%)$, Oil $=$ Kernel oil protein percentage $(\%)$, Starch $=$ Kernel starch protein percentage $(\%), \mathrm{S} \%=$ Shelling Percentage, KY $=$ Kernel yield per hectare $\left(\mathrm{kg} \cdot \mathrm{ha} \mathrm{I}^{-1}\right)$

\section{Cluster Analysis}

Classification of maize hybrids for their heat tolerance was performed on the basis of kernel yield and associated morpho-physiological and kernel quality traits for three consecutive spring seasons under optimal and heat stress conditions by agglomerative hierarchical cluster analysis (AHC) and principle component-based biplots. For the $1^{\text {st }}$ growing season (2017-18), cluster analysis grouped nine maize hybrids into three groups (G-1, G-2 and G-3) under both optimal and heat stress conditions (Figure 2). Under optimal conditions, two maize hybrids YH-5507 and NK8711 were found to be the most productive hybrids and placed under group-1 (G-1) (Table 4). However, three local maize hybrids YH-5507, YH-5427 and YH-5482 were observed to be the most heat tolerant due to their highest kernel yield under heat stress conditions. All the three multinational maize hybrids i.e. NK-8711, DK-6724 and P-1543 were placed in G-2, the group which comprises of the hybrids having average/intermediate tolerance to heat stress as revealed by their kernel yield under stress. 


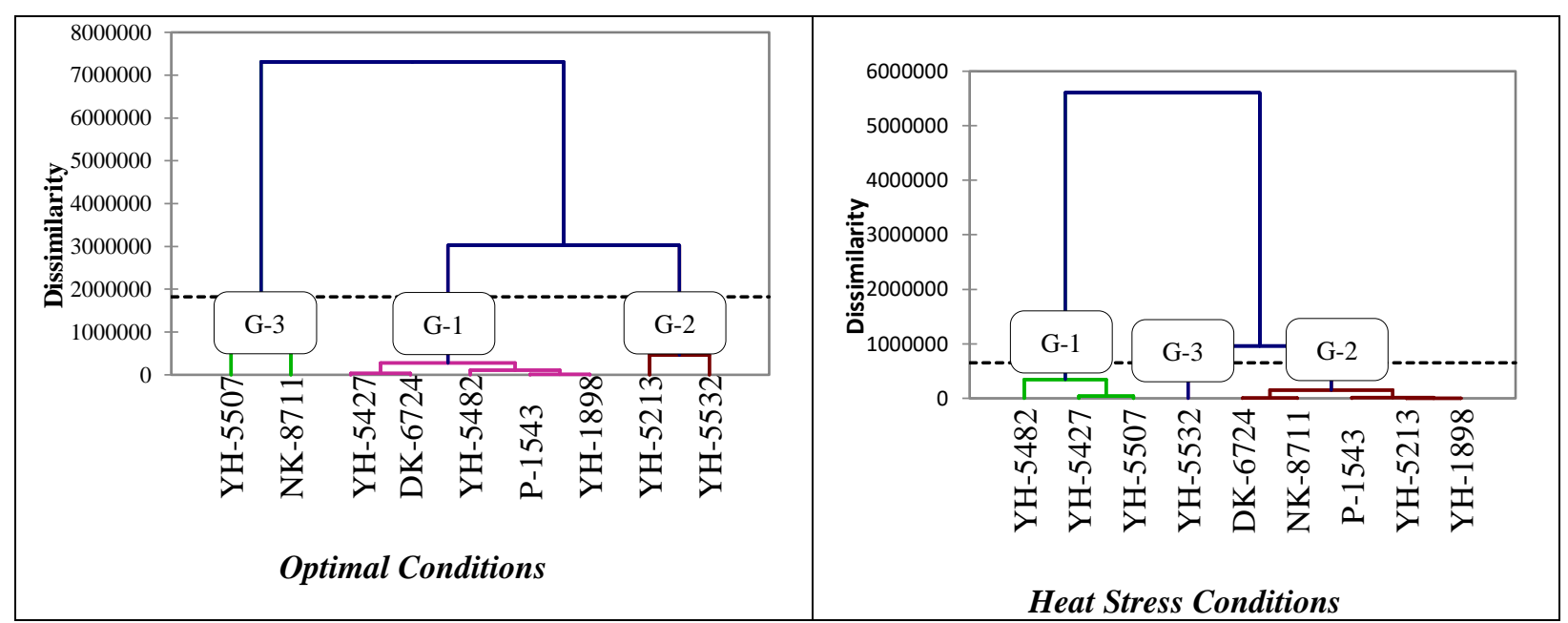

Figure 2. Dendrogram of cluster analysis (Ward's method) among nine maize hybrids optimal and heat stress conditions in Spring, 2017-18

Table 4. Class means for kernel yield and associated traits under optimal and heat stress conditions in Spring 2017-18

\begin{tabular}{cccccccccccc}
\hline & \multicolumn{10}{c}{ Optimal Sowing } \\
\hline Cluster \# & RCI\% & TKW & KC & Pn & C & Pro & Oil & Starch & S\% & KY \\
$\mathbf{1}$ & 56.8 & 322.5 & 607.4 & 23.6 & 221.9 & 13.3 & 4.1 & 51.4 & 86.0 & 10626.1 \\
$\mathbf{2}$ & 59.5 & 298.5 & 690.5 & 14.1 & 211.0 & 13.2 & 4.7 & 51.5 & 83.0 & 9174.0 \\
$\mathbf{3}$ & 56.0 & 285.5 & 711.5 & 30.0 & 260.0 & 13.0 & 4.4 & 51.8 & 87.0 & 12377.3 \\
& & \multicolumn{3}{c}{ Heat Stress Sowing } & & & & \\
Cluster \# & RCI\% & TKW & KC & Pn & C & Pro & Oil & Starch & S\% & GY \\
$\mathbf{1}$ & 57.7 & 283.3 & 565.7 & 21.1 & 233.3 & 13.0 & 4.0 & 50.9 & 86.3 & 10156.3 \\
$\mathbf{2}$ & 61.6 & 254.8 & 570.2 & 18.6 & 252.4 & 12.7 & 4.2 & 50.6 & 84.0 & 8661.0 \\
$\mathbf{3}$ & 64.0 & 264.0 & 569.0 & 13.2 & 231.0 & 12.0 & 3.7 & 51.6 & 80.0 & 7589.0 \\
\hline
\end{tabular}

In $2^{\text {nd }}$ growing season (2018-19), AHC categorized maize hybrids into three groups under optimal conditions while four under heat stress conditions (Figure 3). Under optimal conditions, only a single maize hybrid i.e. YH5427 was placed in the highest productive group (G-1) due to its highest kernel yield (11371 kg ha-1) while two local maize hybrids i.e. YH-5507 and YH-5532 showed maximum heat tolerance by producing maximum yield under heat stress conditions (Table 5). Multinational maize hybrids, in this season again showed intermediate tolerance to heat stress and were placed in G-1 and G-3. Similarly, in $3^{\text {rd }}$ sowing season $(2019-20)$, nine maize hybrids were classified in four groups under optimal conditions while three groups under heat stress conditions (Figure 4). Under optimal sowing conditions, one local (YH-5507) and one multinational maize hybrid (P-1543) out-yielded other hybrids (G-3) while YH-5507 was the most productive and heat tolerant maize hybrid under heat stress conditions (G-2) (Table 6). Multinational maize again showed higher susceptibility towards heat stress and produced lower kernel yield as compared to locally developed hybrids.

Cluster analysis is one of the most popular method used to categorize germplasm of different crop species. In current study, nine indigenous and exotic maize hybrids were classified on the basis of their yield performance under optimal and heat stress conditions. Two local maize hybrids YH-5507 and YH-5427 were characterized as the most productive and heat tolerant maize hybrids across the seasons. Multinational maize hybrids, however, were among the most productive hybrids under optimal conditions but their performance under heat stress conditions was below average, showing their susceptibility towards heat stress. Our results were line with the findings of Meseka et al. (2018) and Nelimor et al. (2019) who successfully classified maize hybrids under heat and drought stress conditions to select tolerant genotypes. 


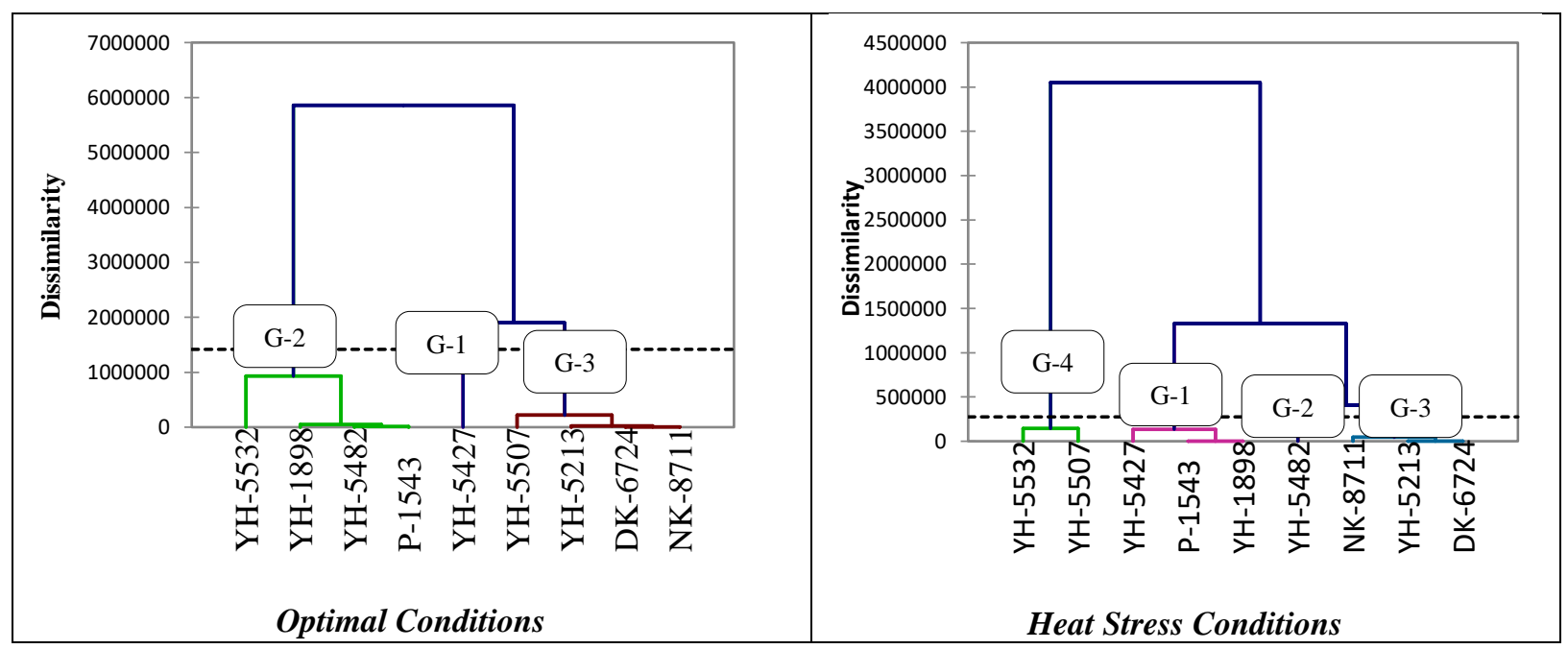

Figure 3. Dendrogram of cluster analysis (Ward's method) among nine maize hybrids optimal and heat stress conditions in Spring, 2018-19

Table 5. Class means for kernel yield and associated traits under optimal and heat stress conditions in Spring 2018-19

\begin{tabular}{cccccccccccc}
\hline & \multicolumn{10}{c}{ Optimal Sowing } \\
\hline Cluster \# & RCI\% & TKW & KC & Pn & C & Pro & Oil & Starch & S\% & KY \\
$\mathbf{1}$ & 66.0 & 342.0 & 689.0 & 25.6 & 226.0 & 13.1 & 4.1 & 50.6 & 87.0 & 11371.0 \\
$\mathbf{2}$ & 63.5 & 310.8 & 597.3 & 19.0 & 197.0 & 13.6 & 4.1 & 51.9 & 85.0 & 8517.8 \\
$\mathbf{3}$ & 61.8 & 295.5 & 674.3 & 24.4 & 259.0 & 12.8 & 4.4 & 51.5 & 86.0 & 9830.5 \\
& & & \multicolumn{3}{c}{ Heat Stress Sowing } & & & & \\
Cluster \# & RCI\% & TKW & KC & Pn & C & Pro & Oil & Starch & S\% & KY \\
$\mathbf{1}$ & 64.0 & 317.7 & 567.7 & 19.4 & 235.7 & 13.5 & 4.0 & 50.9 & 84.7 & 8610.3 \\
$\mathbf{2}$ & 68.0 & 271.0 & 587.0 & 17.7 & 201.0 & 13.3 & 3.9 & 51.7 & 85.0 & 7181.0 \\
$\mathbf{3}$ & 62.0 & 292.3 & 627.0 & 20.0 & 234.7 & 12.1 & 4.3 & 51.4 & 85.0 & 7915.0 \\
$\mathbf{4}$ & 65.0 & 299.0 & 642.5 & 22.9 & 246.0 & 13.4 & 4.0 & 51.7 & 86.0 & 9721.0 \\
\hline
\end{tabular}

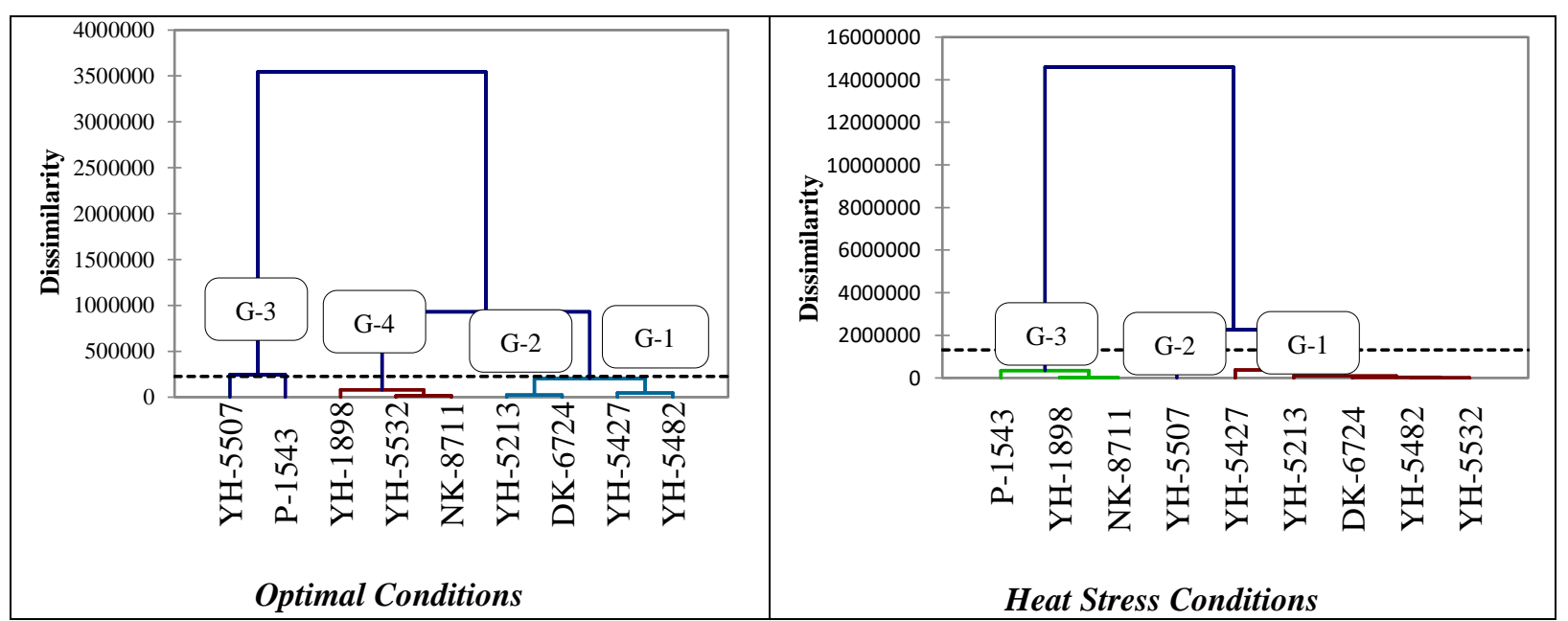

Figure 4. Dendrogram of cluster analysis (Ward's method) among nine maize hybrids optimal and heat stress conditions in Spring, 2019-20 
Table 6. Class means for kernel yield and associated traits under optimal and heat stress conditions in Spring 2019-20

\begin{tabular}{|c|c|c|c|c|c|c|c|c|c|c|}
\hline \multicolumn{11}{|c|}{ Optimal Sowing } \\
\hline Cluster \# & RCI\% & TKW & KC & Pn & $\mathbf{C}$ & Pro & Oil & Starch & $\mathrm{S \%}$ & KY \\
\hline 1 & 55.0 & 313.0 & 645.3 & 22.8 & 228.3 & 13.0 & 4.3 & 51.3 & 85.5 & 9665.5 \\
\hline 2 & 54.0 & 322.0 & 664.3 & 19.7 & 213.7 & 13.2 & 4.2 & 51.5 & 84.7 & 8929.0 \\
\hline 3 & 50.0 & 268.0 & 600.0 & 32.1 & 280.0 & 13.8 & 4.5 & 51.0 & 86.0 & 11208.0 \\
\hline 4 & 58.0 & 301.0 & 589.0 & 25.7 & 267.0 & 13.2 & 3.4 & 52.8 & 86.0 & 10506.0 \\
\hline \multicolumn{11}{|c|}{ Heat Stress Sowing } \\
\hline Cluster \# & RCI\% & TKW & KC & Pn & C & Pro & Oil & Starch & $\mathbf{S \%}$ & KY \\
\hline 1 & 58.0 & 312.4 & 626.4 & 20.4 & 236.2 & 12.9 & 4.0 & 51.2 & 84.0 & 7960.4 \\
\hline 2 & 54.0 & 268.0 & 568.0 & 26.3 & 312.0 & 14.1 & 4.3 & 51.0 & 85.0 & 9602.0 \\
\hline 3 & 59.0 & 319.0 & 600.0 & 18.1 & 254.0 & 13.3 & 3.9 & 51.4 & 82.3 & 5533.0 \\
\hline
\end{tabular}

Principle component analysis based biplots

Principle component analysis based biplots were plotted between Principal Component 1 (PC1) and Principal Component 2 (PC2) to evaluate and categorize maize hybrids on the basis of kernel yield and its associated traits under both optimal and heat stress conditions for three consecutive sowing seasons. In first sowing season (2017-18), PC1/PC2 biplot explained $69.16 \%$ and $68.95 \%$ of the total variation under optimal and heat stress conditions, respectively (Figure 5). Under optimal sowing, biplot revealed the strong, positive correlation of kernel yield with net photosynthetic rate and shelling percentage while negative but non-significant correlation with thousand kernel weight and relative cell injury percentage. However, correlation between kernel yield and thousand kernel weight was significantly positive under heat stress conditions. This might be due to the fact that under heat stress, kernel yield is directly associated with the deposition of starch and other key molecules, which makes the major portion of dry kernel weight. In $2^{\text {nd }}$ sowing season (2017-18), PC-based biplot explained $65.56 \%$ and $58.28 \%$ of the total diversity under optimal and heat stress season, respectively (Figure 6). Kernel yield was found positively correlated with net photosynthetic rate, shelling percentage, stomatal conductance and number of kernels per cob under both conditions. However, thousand kernel weight again was found to have negative association with kernel yield under optimal conditions. Similarly, in $3^{\text {rd }}$ growing season (2019-20), PC1/PC2 biplot contributed $69.48 \%$ and $65.03 \%$ to the total variations (Figure 7 ). Kernel yield was found to be strongly correlated with net photosynthetic rate, shelling percentage and stomatal conductance under both sowing conditions. These results were consistent with the results obtained through correlation coefficient analysis.

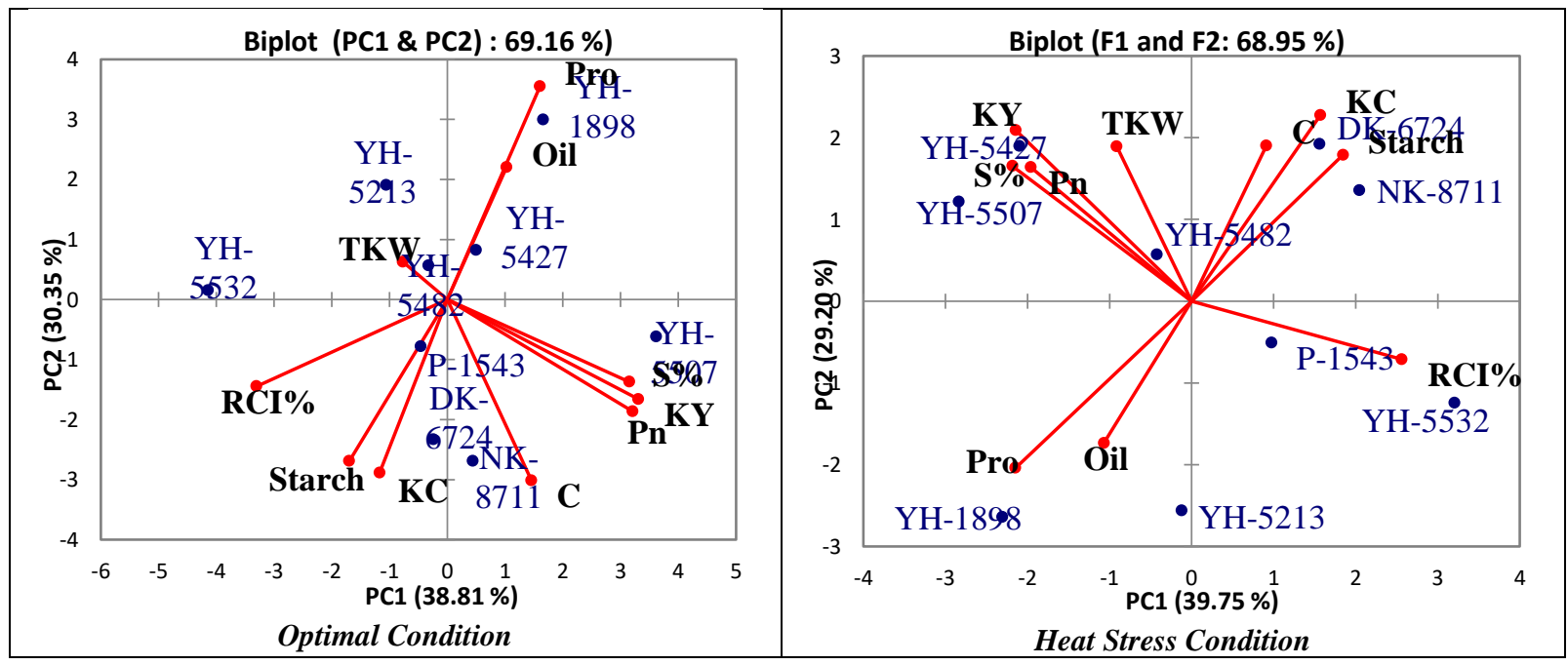

Figure 5. Biplot between PC 1 and 2 displaying contribution of various traits of maize hybrids under optimal and heat stress conditions in Spring, 2017-18 


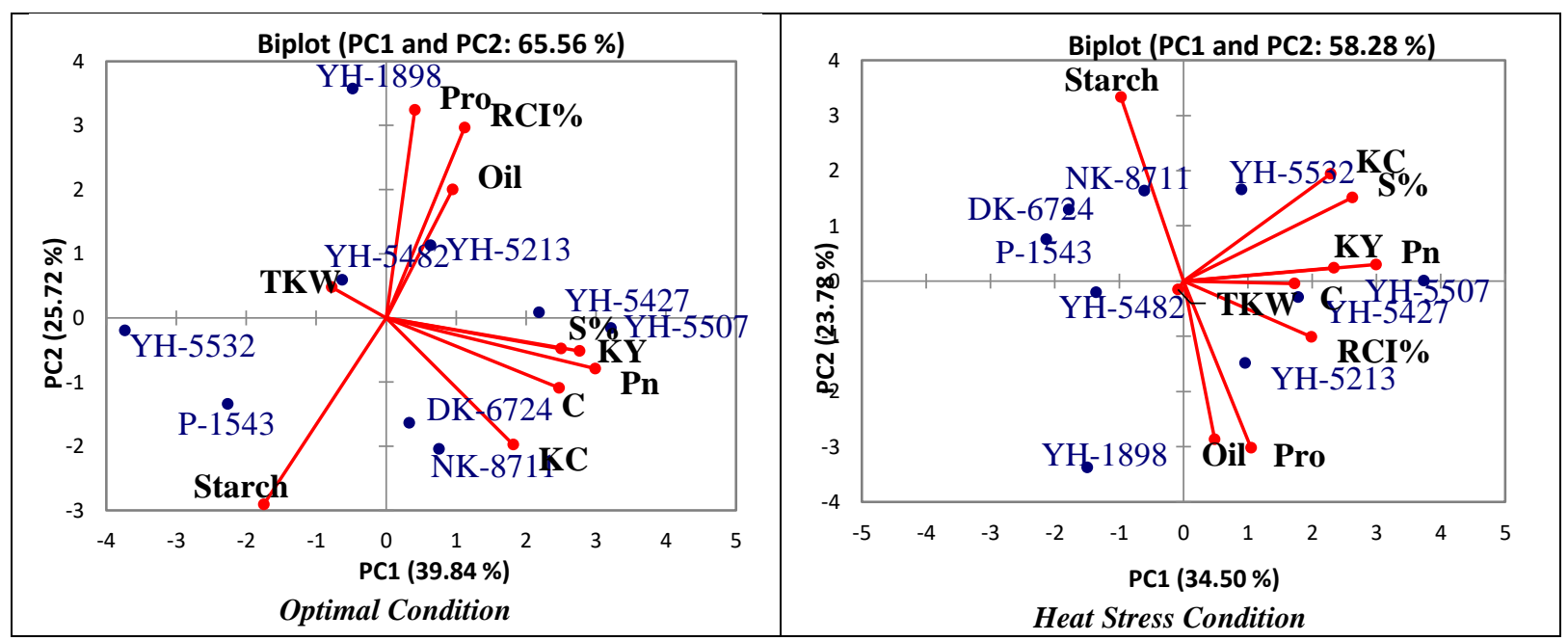

Figure 6. Biplot between PC 1 and 2 displaying contribution of various traits of maize hybrids under optimal and heat stress conditions in Spring, 2018-19

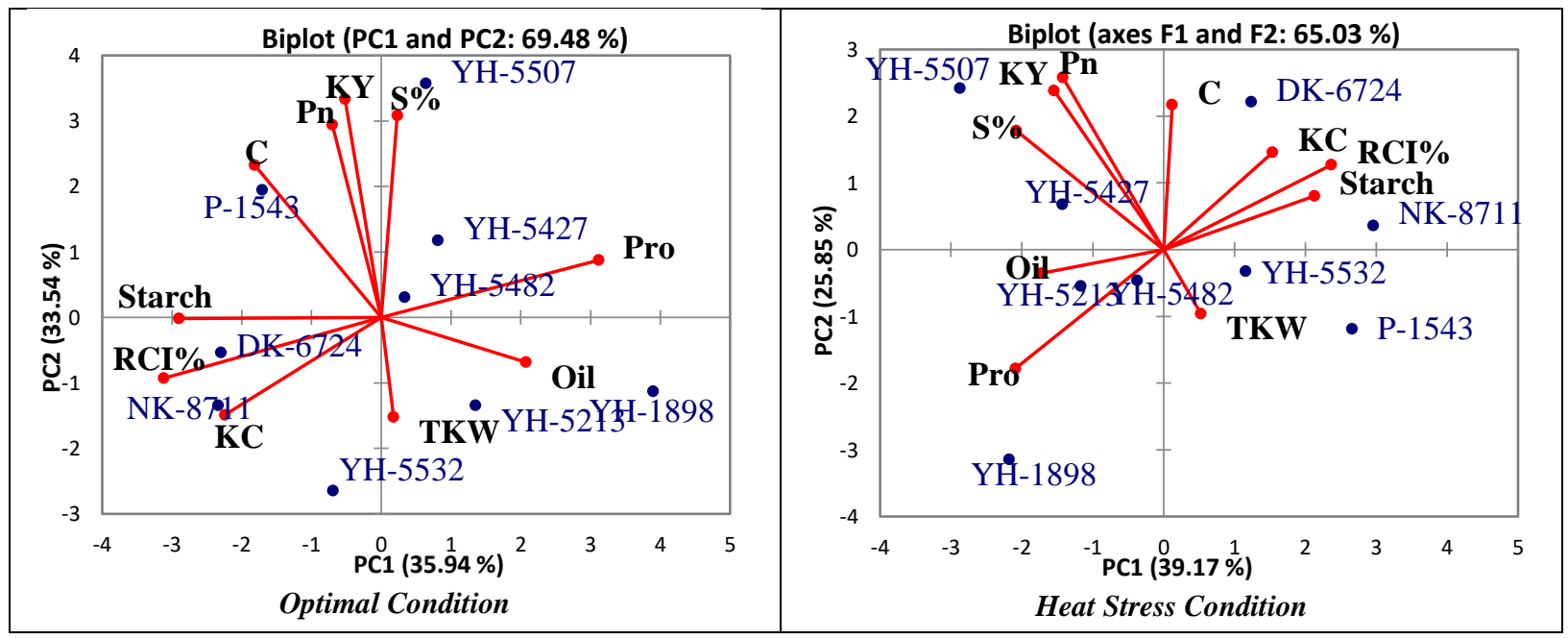

Figure 7. Biplot between PC 1 and 2 displaying contribution of various traits of maize hybrids under optimal and heat stress conditions in Spring, 2019-20

Considering the performance of maize hybrids, $\mathrm{YH}-$ 5427, YH-5507 and YH-5482 were the most productive and heat tolerant hybrids under stress conditions while YH-5532 and P-1543 were the most heat susceptible hybrids due to their lower performance under heat stress as shown by the biplot of $1^{\text {st }}$ sowing season (Figure 5). Similarly, in $2^{\text {nd }}$ growing season, two local (YH-5507 and YH-5427) and two multinational maize hybrids (NK-8711 and $\mathrm{P}-1543$ ) were the most productive hybrids under optimal conditions (Figure 6). However, the productivity and heat tolerance of multinational hybrids under stress conditions was poor. In the $3^{\text {rd }}$ growing season, again local hybrids i.e. YH-5507 and YH-5427 showed maximum kernel yield under heat stress conditions while performance of multinational maize hybrid P-1543 was significantly better under optimal sowing than stress conditions (Figure 7).

Biplot analysis has been widely used by many researchers to evaluate different genotypes for different selection criteria (Ali et al., 2015; Hefny et al., 2017; Marinho et al., 2019). In this study, it was used to compute correlation among different kernel yield related parameters and also to classify maize hybrids on the basis of their heat tolerance ability and productivity under stress conditions. Results revealed that net photosynthetic rate, shelling percentage and stomatal conductance were the most important traits to be considered for the selection of appropriate genotypes to develop heat resilient maize hybrids. Similar results were also reported by Yousaf et al. (2018) who showed that maize kernel yield has a direct positive correlation with net photosynthetic rate and shelling percentage under heat stress conditions. Moreover, the productivity of local maize hybrids under heat stress conditions was better than multinational hybrids.

The hybrids having higher PC1 values are considered as best performing hybrids under optimal and stress conditions while the hybrids with higher PC2 values 
generally reflects the higher stress susceptibility. Therefore, we can designate PC1 for yield potential while PC2 for stress susceptibility. The cumulative results obtained from six PC1/PC2 biplots revealed that two local maize hybrids $\mathrm{YH}-5507$ and $\mathrm{YH}-5427$ were the most productive hybrids across the seasons and under both optimal and heat stress conditions. However, one local (YH-5532) and two multinational (P-1543 and DK-6724) maize hybrids showed moderate susceptibility towards heat stress. Similar findings were also reported by Yousaf et al. (2017) and Ghani et al. (2018) who revealed that heat susceptibility of late sown spring hybrids was higher in multinational hybrids as compared to locally produced hybrids. Furthermore, our results were in complete agreement with Singh et al. (2015) who showed that the genotypes having higher PC1 values are the most productive while the genotypes having higher PC2 values were less heat tolerant.

\section{CONCLUSION}

In conclusion, highly significant differences were observed among maize hybrids under optimal and heat stress conditions across three growing seasons, enabling efficient identification of donors for heat tolerance. Correlations analysis revealed significantly positive correlation of kernel yield with net photosynthetic rate, thousand kernel weight and shelling percentage while strong negative correlation with relative cell injury percentage under heat stress conditions. Therefore, these parameters should be included in the selection criteria for the development of heat tolerant maize hybrids. Cluster and principle component-based biplot analysis characterize maize hybrids into different groups depending upon their performance and tolerance to heat stress conditions. The results showed that locally developed maize hybrids especially $\mathrm{YH}-5507$ and $\mathrm{YH}-$ 5427 were more heat tolerant under late sowing conditions of spring seasons while multinational maize hybrids i.e. NK-8711, P1543 and DK-6724 showed better performance under optimal conditions only, making them susceptible to heat stress. Introgressions of abovementioned heat tolerant maize hybrids into breeding program will help in achieving maximum genetic gain under heat stress conditions.

\section{ACKNOWLEDGMENTS}

The authors are grateful to the field staff of the Maize and Millet Research Institute, Yusafwala for their efforts. The authors thank Dr. Abid Mehmood, Director General Agri. Research (Punjab) and the Government of Punjab for their support. Thanks, are expressed to K. Shashok (Author AID in the Eastern Mediterranean) for improving the use of English in the manuscript.

\section{LITERATURE CITED}

Ali, F., N. Kanwal, M. Ahsan, Q. Ali, I. Bibi and N.K. Niazi. 2015. Multivariate analysis of grain yield and its attributing traits in different maize hybrids grown under heat and drought stress. Scientifica 563869: 1-6

Brown L, 2009. Plan B 4.0: Mobilizing to save civilization. W.W. Norton \& Company, New York.
Cheema, U.K., N. Akhtar, M. Arshad and M. I. Yousaf. 2020. Characterization of maize inbred lines for grain yield and related traits under heat stress conditions. Int. J. Biol. Biotech. 17: 367-375.

Cicchino, M., J.I.R. Edreira and M.E. Otegui. 2010. Heat stress during late vegetative growth of maize effects on phenology and assessment of optimum temperature. Crop Sci. 50: 14311437.

Coskun, Y., A. Coskun, U. Demirel and M. Ozden. 2011. Physiological response of maize (Zea mays L.) to high temperature stress. Aust. J. Crop. Sci. 5: 966-975.

Dass, S.I., G.K.C. Singh, C.M. Parihar, A. Singode and M.D.K. Singh. 2010. Abiotic stresses in maize, some issues and solutions. Directorate of Maize Research Pusa Campus, New Delhi.

Ghani, A., M. I. Yousaf, M. Arshad, K. Hussain, S. Hussain, M.T. Mukhtar, A. Hussain and S. Rehman. 2017. YH-1898: A new high yielding, high temperature tolerant local yellow maize (Zea mays L.) hybrid. Int. J. Biol. Biotech. 14: 441449.

Govt. of Pakistan. 2018-19. Economic survey of Pakistan, Ministry of Finance, Govt. of Pakistan, Islamabad. Available at http://www.fnance.gov.pk/survey 1819.html

Hefny, M.M., A. A. Ali, T.Y. Byoumi, M. Al-Ashry and S. A. Okasha. 2017. Classification of genetic diversity for drought tolerance in maize genotypes through principal component analysis. J. Agric. Sci. 62: 213-227

Iqbal, M A., J. Eitzinger, H. Formayer, A. Hassan and L.K. Heng. 2011. A simulation study for assessing yield optimization and potential for water reduction for summersown maize under different climate change scenarios. J. Agric. Sci. 149: 129-143.

Kandel, M., S.K. Ghimire, B.R. Ojha, and J. Shrestha. 2017. Analysis of genetic diversity among the maize inbred lines (Zea mays L.) under heat stress condition. Journal of Maize Research and Development 3: 86-97.

Khodarahmpour, Z. 2012. Morphological classification of maize (Zea mays L.) genotypes in heat stress condition. J. Agr. Sci. 4: $31-40$

Marinho, J.D.L., D.S.D. Costa, D.U.D. Carvalho, M.A.D. Cruz and C. Zucareli. 2019. Evaluation of vigor and tolerance of sweet corn seeds under hypoxia. J. Seed Sci. 41: 180-186.

Meseka, S., A. Menkir, B. Bossey and W. Mengesha. 2018. Performance assessment of drought tolerant maize hybrids under combined drought and heat stress. Agronomy 8: 1-17

Nelimor, C., B. Badu-Apraku, A.Y. Tetteh and A.S. N'guetta. 2019. Assessment of Genetic Diversity for Drought, Heat and Combined Drought and Heat Stress Tolerance in Early Maturing Maize Landraces. Plants 8: 518.

Noor, J.J., M.T. Vinayan, S. Umar, P. Devi, M. Iqbal, K. Seetharam and P.H. Zaidi. 2019. Morpho-physiological traits associated with heat stress tolerance in tropical maize (Zea mays L.) at reproductive stage. Aust. J. Crop Sci. 13: 536545.

Rahman, S.U., M. Arif, K. Hussain, S. Hussain, T. Mukhtar, A. Razzaq and R.A. Iqbal. 2013. Evaluation of maize hybrids for tolerance to high temperature stress in central Punjab. Amer. J. Bioeng. Biotech. 1: 30-36.

Saeed, M., A. Mumtaz, D. Hussain, M. Arshad, M.I. Yousaf and M.S. Ahmad. 2018. Multivariate analysis-based evaluation of maize genotypes under high temperature stress. I3 Biodiversity, 1.

Sanchez, B., A. Rasmussen and J.R. Porter. 2014. Temperatures and the growth and development of maize and rice: a review. Global Change Biol. 20: 408-417.

Serna-Saldivar, S.O. 2018. Corn: Chemistry and technology, 3rd Edition. AASS International, Elsevier Inc., USA. 
Shehzad, A., M.I. Yousaf, A. Ghani, K. Hussain, S. Hussain and M. Arshad. 2019. Genetic analysis and combining ability studies for morpho-phonological and grain yield traits in spring maize (Zea mays L.). Int. J. Biol. Biotech. 16: 925931.

Singh, C., V. Kumar, I. Prasad, V.R. Patil and B.K. Rajkumar. 2016. Response of upland cotton (G. hirsutum L.) genotypes to drought stress using drought tolerance indices. J. Crop Sci. Biotechnol. 19: 53-59.

Steel, R.G.D., J.H. Torrie and D.A. Dicky. 1997. Principles and Procedures of Statistics: A biometrical approach, 3rd Ed. McGraw Hill Book Co., New York, USA.

United State Department of Agriculture. 2020. World Agricultural Production. United State Department of Agriculture, Circular series, WAP 04-20.

Yousaf, M.I., K. Hussain, S. Hussain, R. Shahzad, A. Ghani, M. Arshad, A. Mumtaz and N. Akhter. 2017. Morphometric and phonological characterization of maize (Zea mays L.) germplasm under heat stress. Int. J. Biol. Biotech. 14: 271278.

Yousaf, M.I., K. Hussain, S. Hussain, A. Ghani, M. Arshad, A. Mumtaz and R. A. Hameed. 2018. Characterization of indigenous and exotic maize hybrids for grain yield and quality traits under heat stress. Int. J. Agric. Biol. 20: 333337.

Yousaf, M.I., K. Hussain, S. Hussain, A. Ghani, A. Shehzad, A. Mumtaz, M. Arshad, A. Mehmood, M. U. Khalid, N. Akhtar and M. H. Bhatti. 2020. Seasonal influence, heat unit accumulation and heat use efficiency in relation to maize grain yield in Pakistan. Maydica 64: 1-9. 